\title{
SPATIAL PLANNING AND TRANSFORMATIONS IN THE SPATIAL STRUCTURE OF ZAGREB
}

\author{
Vedran Prelogović*, PhD., Tomislav Pintarić**, M.A., \\ Dražen Njegač*, PhD. \\ *Department of Geography, Faculty of Science, University of Zagreb

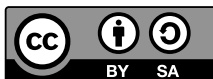 \\ Marulićev trg 19/II, 10000 Zagreb, Croatia \\ ***agnedje I, 10000 Zagreb, Croatia \\ e-mail:vprelogo@geog.pmf.hr, pintarictl4@hotmail.com,dnjegac@geog.pmf.hr
}

Original scientific article

COBISS 1.01

DOI: 10.4312/dela.46.6.143-162

\begin{abstract}
Paper discusses the characteristics of the urban development of the City Zagreb by analysing the development of spatial planning and the changed power relations. During the last 20 years, the transformations have been mainly negative and have had important impact on changing the structure of residential, commercial and business zones, and on conversion of the industrial and military areas.
\end{abstract}

Key words: Zagreb, spatial planning, urban transformations, economic transition, urban spatial structure

\section{PROSTORSKO NAČRTOVANJE IN PREOBRAZBE PROSTORSKE STRUKTURE ZAGREBA}

\section{Izvleček}

Prispevek naslavlja značilnosti urbanega razvoja Zagreba z analizo razvoja prostorskega načrtovanja in spremenjenih odnosov moči. V zadnjih dvajsetih letih so bile preobrazbe večinoma negativne in vplivajo na spreminjanje strukture stanovanjskih, trgovskih in poslovnih con, pa tudi na preureditev industrijskih in vojaških območij.

Ključne besede: Zagreb, prostorsko načrtovanje, urbane preobrazbe, gospodarski prehod, urbana prostorska struktura

\section{INTRODUCTION}

Post-socialist cities in Europe have been largely transformed during the last 20-30 years. The new economic, political and institutional framework had multiple effects on the development and management of cities. This is particularly evident in redefining the activities 
of spatial planning (Dimitrovska Andrews, 2005), which directs the development of the city and its parts in accordance with the new power relationships, and this directly affects the changes in the spatial structure of the city (physiognomic and morphological, functional and social components; Kostinskiy, 2001; Sýkora, 1994, 1999). Furthermore, the transformations are reflected in housing construction, the increased tertiarisation, neglect of industrial and military complexes, etc. Kovács (1999) speaks of a new urban order and transition cities are marked by significantly different characteristics from those from the socialist period.

Accordingly, the new socio-economic and institutional context encouraged considerable urban transformations in the spatial structure of Zagreb. Under the influence of transitional changes, new or modified existing spatial patterns have appeared in Zagreb. They are similar to those in other post-socialist cities, and increasingly take on the characteristics of the cities in the developed countries of Western and Central Europe, and in some respects even of Anglo-American cities (e.g. in the construction of business centres; Zlatar, 2013).

Due to the strengthening of private property, the real estate market and increasing liberal activities of foreign and domestic investors, the neoliberal framework of development significantly influenced the changes in the spatial structure of Zagreb. New power relationships are primarily evident in the strengthening of economic actors, constructing mostly negative impact on that activity, and consequently on the development of the city in the transition period. In the newer period, the legal framework and the resulting planning documents defining and directing the development of the city have undergone frequent changes.

Paper analyses the transitional characteristics of the development of Zagreb by analysing the development of spatial planning and the changed power relations. Furthermore, it will present key urban transformations that have occurred over the last 20 years. More specifically, in the context of strategic thinking and public interest, in the transitional period the Zagreb area was threatened more than ever, mainly by negative interventions in housing construction, commercial and business zones, and the conversion of industrial and military areas. The objective is to detect changes in the spatial structure of Zagreb that have occurred under the influence of the transition processes. We argue that the frequent changes within the legislative and spatial planning framework and the economic transition are key factors that have contributed to urban transformations. The spatial framework of the research is the City of Zagreb, which is a territorial and administrative unit with the status of local and regional government. The City of Zagreb includes 70 statistical settlements (including the two urban settlements of Zagreb and Sesvete, which are completely fused in terms of morphology and physiognomy) within 17 city districts on a surface of 641 square kilometres.

\section{METHODS}

The methodology in this paper includes an analysis of the legal framework of spatial planning in Croatia and Zagreb during the transition period. The acts (Act on Spatial Planning, Act on Spatial Planning and Construction) that were passed in 1990s and 
2000s, with several amendments, significantly changed the way of creating and implementing decisions. In this context, particular emphasis is given on the impact that acts had on the creation of spatial plans. Furthermore, at the City level the role of strategic and implementation plans is analyzed, with emphasis on significance of certain spatial planning documents. Therefore, the focus is put on the implementing documents (urban plans) that directly affect the changes in the spatial structure of the city, which is evident in residential construction, especially on the city edge. The special attention is payed to the emergence of new actors and changed power relations in spatial planning, which consequently, affects the planning process that is driven primarily by locational requirements and profits. Areas that were transformed during the last 20-25 years (residential, commercial, business and industrial/military) were analyzed using the data from official statistical sources of the City and field research conducted during the summer and fall of 2016. The field research was a ground for functional zoning of the city. Four areas were identified in which the visible changes occurred during the transition period, and often at odds with the official documents.

\section{LEGISLATIVE AND SPATIAL PLANNING FRAMEWORK}

Zagreb has a long tradition of spatial planning which has been affected by different socio-economic and political conditions in which the city has developed. Since the mid-19 $9^{\text {th }}$ Century, when the first spatial plans were developed, a number of plans have been adopted to direct and follow the development of the city.

The second half of the $20^{\text {th }}$ Century was especially important period of affirmation of the spatial planning practice, which coincided with intense and dynamic spatial expansion, demographic and economic growth, when Zagreb surpassed the local dimension and became a city of broader regional and national importance. Thus, during the socialist period, the development of planning documents for the city and some of its parts had a clearly defined hierarchical organisation. The practice was very intense when, in accordance with the ideology of self-managing socialism as a combination of planning, market and self-management, a specific relationship to space was defined. In accordance with the legal and institutional development, which was based on community planning, spatial planning institutes were developing various regional, general, master and detailed plans (Crljenko, 2012). During certain periods, the preparation of detailed planning documentation was completely ignored, whilst today it is the most important instrument for the development of the city. Its implementation was usually based on strict zoning of area purposes and rational settings which were difficult to achieve in practice. The role of individual groups in the planning process, such as citizens, public institutions, municipalities and investors, was determined by law, but in practice they did not have a big role because the main role was played by leading politicians and planning experts who monitored the technical aspects and implemented their ideas. At the beginning of 1990s, the relations between planners and other stakeholders concerned by the issues of local development management, such as the public, city government and economic actors, were replaced by a more flexible approach to space (Cavrić, Nedović-Budić, 2007). 
Croatian independence was followed by political and institutional changes that greatly affected spatial planning in the new socio-economic, i.e. transitional context (MrakTaritaš, 2008). A prerequisite to establishing new laws and regulation of relations between actors in the spatial planning was the new territorial organisation adopted in 1992 through the Act on Counties, Cities and Municipalities [Zakon o područjima županija, gradova $i$ općina] (1992), which divided the Croatian territory into 21 counties including the City of Zagreb. The new legislative framework in the field of planning started in 1994 by passing the Act on Spatial Planning [Zakon o prostornom uređenju] (1994) with a number of amendments (Act on Spatial Planning, 1994; 1998; 2000; 2002; 2004). It defined the structure and hierarchy of spatial planning documents and a system of spatial planning for the entire Croatian territory, with a commitment to harmonise the spatial planning documents of lower territorial units with spatial planning documents of higher territorial units.

However, the legislation of the 1990s and early 2000s has shown some weaknesses as it prescribed the development of a large number of spatial plans requiring a long period of preparation, low potential for public participation in its development, and weak monitoring of plan implementation. Furthermore, due to lack of time, sub-legal acts were passed quickly, unprepared and unconnected. Given the visible consequences in space, it can be said that spatial planning has failed to adapt to new social and economic circumstances, which opened the way to a liberal and more flexible development of space, in some places with chaotic and irreversible consequences. This reduced the importance of the spatial planning profession, thus enabling a large number of interventions, which are often difficult to control. The competence for the preparation of spatial planning documents in this strict system of spatial plan development was assigned to numerous public and private companies, resulting in a large number of conflicting plans based on unrealisable goals, which is evident in today's planning practice.

In 2007 the new Act on Spatial Planning and Construction [Zakon o prostornom uređenju i gradnji] (2007) was adopted. This act began the adaptation of legislation to European practices of planning; it established the system of planning and construction, the competence of government bodies and bodies of local and regional governments and the division of the planning documents on strategic and implementation.

Apart from the legislative framework, the documents important for the development of Zagreb, are spatial planning documents used since the 1990s, which are defined by these laws. Strategic plans are the following: Spatial Plan of the City of Zagreb and Master Plan of Zagreb and Sesvete, while the implementation plans are: Urban Plan, Detailed Plan (which was later abolished) and Urban project.

The Spatial Plan of the City of Zagreb defined conditions for the development of the City, which determines the purposeful use, purpose, design, renovation and repair of the construction and other land, protection of the environment and cultural monuments and valuable parts of nature (Mrak-Taritaš, 2008). The area for which the above conditions apply covers an area of 641 square kilometres with 70 settlements, and 17 city districts in which the objectives of regulation are achieved.

The Master Plan of Zagreb and Master Plan of Sesvete have a dual role as they are both the strategic and implementation documents determining the future shape of the 
city through regulations, the requirements of building and defining urban rules for certain parts of the city. They define the use and purpose of areas, a network of economic and social activities, transport and utility infrastructure and conditions for the use, development and protection of the area (urban policies, procedures for urban spatial planning, protected natural areas and immovable cultural property; Master Plan, 2015). Master plans prescribe the use and purpose of areas, which is a very important item for the drafting of implementing documents of lower levels that determine the spatial development of settlements or parts of settlements. The proper zoning of certain purposes in the urban area achieves basic spatial and functional solutions and creates conditions for the planning of certain parts of the city.

Urban Plan in the City of Zagreb serves as the implementing document. It is usually adopted for parts where there is new spatial regulation and construction. It can be conversion of land (former industrial plants or former military barracks) and completion of areas for residential and mixed use. In terms of urban transformations, master plans are the most visible and the most common form of transformation of the spatial structure of the city, and are reflected in the demolition, new construction and revitalisation.

Urban projects represent an important implementation document. The practice of urban projects in European cities is based on different concepts of defining the urban project, but what they have in common is the existence of their long-term, well planned, and controlled implementation. This is usually accomplished through stages from 20 to 30 years. In Croatia, this is not the case due to inadequate political support, funding sources and non-defined relationships of public-private partnership. Compared with other Croatian and European cities, Zagreb has vague criteria for defining urban projects, leading to confusion in the way of their announcement and a number of other problems (Jukić, 2012). Most cities use projects to perform urban renewal, urban reconstruction and revitalisation of abandoned areas, to improve the quality of housing through the new construction of residential areas in the abandoned brownfield or greenfield sites, while in Zagreb, it is mostly a way to circumvent the drafting of implementing documents and interpolating content to specific locations. Urban projects in Zagreb include all buildings with more than nine floors and areas of more than 1 hectare that are owned by the city, state, or companies and public institutions owned by the City. According to this decision, all surfaces larger than 1 hectare and owned by the city are exempt from existing rules of the Master Plan and maximum building coverage can be allowed there regardless of the area's actual purpose.

From 1998 to 2013, there were 229 implementing documents in the City of Zagreb of which 87 were adopted, and the remaining 142 were required to be drafted. The majority of 87 adopted plans relates to the edges of the city, mainly focused in the residential new construction, which is associated with larger building surfaces.

From the foregoing, it is clear that the legal framework and spatial planning documents play a very important role in the transformation of transitional Zagreb. Ad hoc legislation adoption, frequent discrepancies between acts and spatial planning documents have contributed to the image of the spatial structure of Zagreb nowadays. 


\section{TRANSITIONAL PROCESSES IN ZAGREB}

Undoubtedly, the changed and the emerging legal framework with spatial planning documents have triggered changes in the spatial structure of the city. Transition planning, therefore, borders two social and economic systems. Socialist planning forms have been replaced by a rather centralised city government, and the planning process is being developed within the framework of neoliberal strategies, in which the private, and the associated privatisation, is gaining importance. The transition from one to another system crash means the collision of the public, i.e. social interest with private interests at the expense of the planning practice. City planning becomes more flexible, the city is no longer planned as a whole, but as an object, and the management was replaced by urban entrepreneurship (Gulin-Zrnić, 2013).

During the transition, the market becomes a major regulatory mechanism in the development planning of a city. In the context of the weakening of the planning system, there is a growing trend of private investment in the land, and their value is becoming the main resource of the development policy. Placing the emphasis on site investment leads to the absence of developmental impact, while the participation of relevant stakeholders takes second place. Therefore, the critics of transition in Zagreb list the dangers and threats to spatial planning and its sustainability (Svirčić Gotovac, 2012; Pegan, 2012; Zlatar, 2013).

Caldarović (2012) explains that transition is characterised by the disruption of planning an integrated city; instead, there is construction of individual units scattered within the city. A transition city thus becomes an arena where planning "happens" based on individual projects. The modern "rampant capitalism" determined by the transitional character of "incompleteness" causes various forms of "manoeuvring" and the result is a specific "project", "spot" or "object" planning driven primarily by site requirements. Unlike the key role played by the state in the field of spatial planning in the previous system, the revised relations of stakeholders in the modern city have reduced its impact and introduced the private sector into the system. The participation of the public in this relationship is often symbolic (Čaldarović, 2012). Seferagić (2007) calls into question the very existence of urban planning based on disadvantaged relations of urban planners and their role in protecting the public interest in the neoliberal stage of planning considerations.

In the 1990s, the development of Zagreb and other post-socialist cities faced a change in power relations between stakeholders who have an impact on spatial changes. In his 11 theses, Bassand (2001) explains the complex, conflicting urban reality composed of a system of stakeholders within which a certain group of actors manages, while other groups oppose. He associates the stakeholders with a certain position in society, resulting in interests, relations with other actors, identities and unequal access to resources within society, which then create a hierarchy of power. Stakeholders may be divided into:

- political stakeholders: political parties and political leaders, stakeholders from strong companies with political influence;

- economic actors: entrepreneurs, both foreign and domestic companies, banks and developers;

- professional actors: architects, planners, surveyors, geographers, ethnologists, sociologists, ecologists and all the other spatial experts; 
- civil actors: civil organisations and citizens identified according to social position, age, education, etc. (Bassand, 2001; Seferagić, 2007; Svirčić Gotovac, Zlatar, 2015).

The new system of stakeholders in the transition conditions leads the processes of transformation of urban structures that now make up the contemporary reality of post-socialist cities. In Zagreb, a number of examples of urban change is considered as a result of altered power relations among stakeholders, which led to a new, post-socialist stage of urban development.

Slavuj, Cvitanović and Prelogović (2009) in their research of the spatial structure of Zagreb, listed four types of problem areas, taking into account the characteristics and changes in functional and morphological components:

- converted: parts of the city transformed into commercial, residential and private areas during the 1990s and 2000s;

- new built: mainly residential and commercial construction on the peripheral areas of the city triggered by suburbanisation, tertiarisation and market opening;

- densely built: unplanned residential areas within existing settlements of Zagreb, without adequate infrastructure or compliance with existing morphological characteristics, and as a result of poor or even a lack of spatial planning and law enforcement;

- neglected: mostly non-validated industrial sites, areas along the rail road and old factories in suitable locations in the wider city centre.

The above problem areas reflect the transformations of post-socialist Zagreb with often chaotic forms of spatial development as a result of a decreasing importance of spatial planning and the marginalisation of some stakeholders such as citizens and professionals.

During the transition, substantial transformation has occurred on the real estate market, which has experienced tremendous growth. Consequently, it has affected the price increases, causing a boom in housing construction and the construction of business premises at some stages of development. Furthermore, the development of the real estate market has led to a differentiation of urban space. The value of real estate and land in the central parts of the city grows, which attracts different investors in commercial facilities such as retail stores, restaurants and banks. There is a change of the social component of the city's spatial structure, and also a socio-spatial polarisation (Prelogović, 2004; 2009). For example, in the central city districts Donji grad and Gornji grad-Medveščak, total population was reduced to just over 30,000 in the period from 1991 to 2011 . At the same time, the suburbanisation process intensified, especially in the marginal urban areas of eastern, south eastern and southern periphery.

Residential suburbanisation was followed by the decentralisation of various commercial functions, business areas, and industries on the edges of the city and along the main roads of favourable transportation position, while in the broader city centre, less specialised shops, crafts and workshops are closed due to overwhelming competition (Jakovčić, 2006; Seferagić, 2007; Sić, 2007).

In the central parts of city, there are deserted areas remaining behind some industrial sites, the legacy of the former socialist industry. Due to unresolved property relations, weak profitability and high costs required for their rehabilitation, brownfields are kept within the city. The investment cycle is initiated by the construction of shopping centres, 
new housing and commercial complexes at the expense of existing land and their (degrading) infrastructure and public spaces. Land becomes an extremely valuable resource in the transitional urban development.

\section{URBAN TRANSFORMATIONS IN ZAGREB}

In the transition period, especially after the 2000s, there were major changes in the spatial structure of Zagreb. Centuries-long development of the city adapts to the neoliberal context leading to changes in all spheres of life, which encourages a dynamic and turbulent development. Changes in land use associated with the strengthening of private initiatives have created new elements in the spatial structure of the city, especially in the functional and morphological component. The city changed significantly through the construction and the introduction of new elements, the conversion of the old and the completion of certain parts of the urban fabric through reconstruction and revitalisation. Urban transformation in Zagreb will be explained in a more detailed analysis of residential, commercial, business and industrial-military areas (Figure 1).

Figure 1: Transformed residential, commercial, business and industrial-military areas in the City of Zagreb.

Slika 1: Preobrazba stanovanjskih, trgovskih, poslovnih in indusrijsko-vojaških območij v Zagrebu.

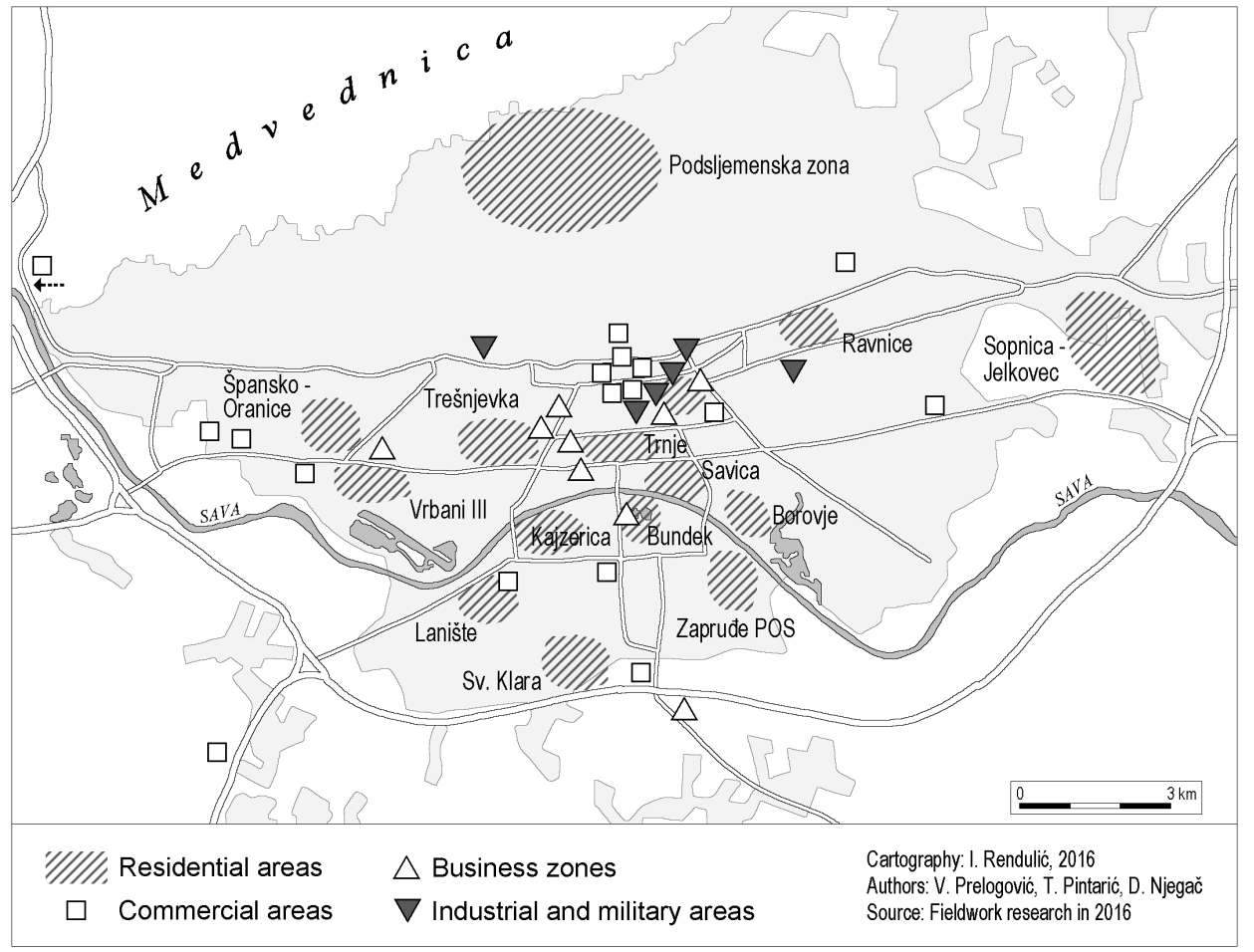




\section{I Residential areas}

Transitional changes significantly affected the residential function in Zagreb. As has been repeatedly pointed out, privatisation was a key process allowing the change of ownership relations in the management of real estate and land (Mlinar, 2009). The pre-transition chronic lack of housing was additionally aggravated by the arrival of people from war zones and migrations within the city. In particular, this relates to the events during the war that had a negative impact on investment in residential construction during the 1990s. During the transition, the dynamics of the construction of residential buildings was in line with economic trends which started to improve in the late 1990s as a result of the increase in demand and purchasing power.

Although in the inter-census period (2001-2011) Zagreb had an increase in population of several thousand, this did not play key role in the growth of the housing market, but in a reduction in average household size. This means that intensive housing construction decreased the quantitative statistical housing shortage, i.e. the negative difference between households and flats, while in qualitative terms that number was much higher, because a larger number of flats are located in buildings of lower quality. Thus, increased demand is a result of the need to improve the quality of housing (Bašić, 2005).

The quantitative indicator clearly reflecting the dynamics and changes in housing is the number of apartments built. In the period from 1991 to 2014, 83,883 new apartments were built in Zagreb. During the first ten years of transition, 24,927 or $29.7 \%$ of the apartments were built. This was a stage of transition marked by war and post-war events and weaker economic opportunities, so the level of housing construction was quantitatively lower. The real boom in housing construction and major changes in the real estate market began in the early 2000s, leaving an indelible mark in the function and morphology of the city.

The key stage of housing construction occurred in the period between 2001 and 2010, during which increase was recorded year by year. The peak was reached in 2006, 2007, and 2008, when more than 6,000 apartments were built at an annual level (8,895 apartments in 2007 and 8,744 in 2008). $57.3 \%$ of all apartments in the transition period were built during this construction boom. A large disturbance in the construction sector came in 2010 when an abrupt decrease in new buildings occurred as a result of the economic crisis; for example, only 638 apartments were built in 2014, which is 14 times less than in the record year of 2007 (Figure 2).

During the transition, construction activities occurred in almost all parts of Zagreb. The new planned housing developments were built on the free undeveloped or converted land (former industrial sites and military barracks) mainly in the outskirts of the city (Borovje, Lanište, Sopnica-Jelkovec, Špansko, Vrbani III, etc.). Sopnica-Jelkovec is the best-known example of a new residential area on the outskirts of the city, located on the site of a former pig farm in Sesvete. The construction was financially supported by the so-called Zagreb model of housing construction, which sought to provide apartments for low-income families. Accordingly, a large residential area was built, with around 2,700 apartments which were exposed to a series of criticisms by residents and 
experts following the opening. Criticisms were directed at the poor planning of the settlement and construction: too dense buildings, lack of green areas, parking lots and other services.

Figure 2: Number of built apartments in the City of Zagreb between 1991 and 2014.

Slika 2: Število izgrajenih stanovanj v Zagrebu v obdobju 1991-2014.

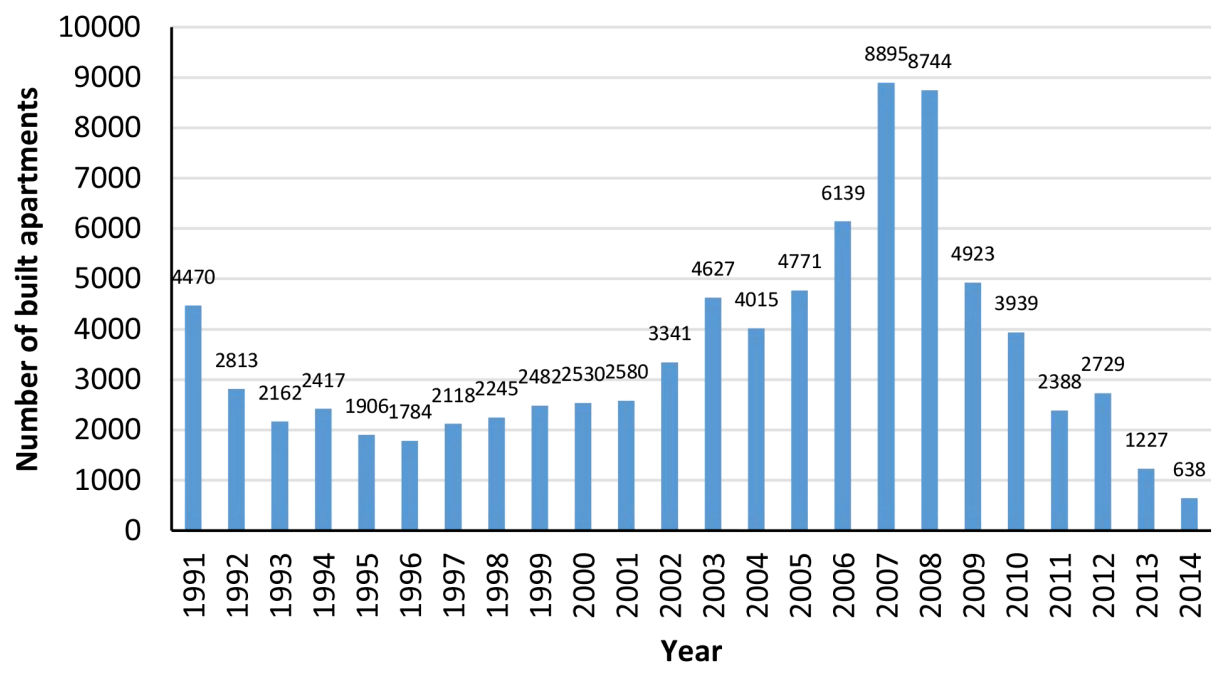

Source/Vir: Statistical Yearbook of the City of Zagreb (Statistički ljetopis Grada Zagreba), 1999; 2015.

In other parts of the city, there were also numerous interventions by various individual users (residents), investors, builders and developers who often fail to comply with the regulations or to interpolate objects, which do not fit into the urban landscape visually and morphologically. Those solutions are often partial as a result of poor control, failing to contribute to quality design, but suggest an inappropriate approach to urban development. Since the goal is to create the largest possible profit, oversized buildings are constructed and there is a significant increase in building density. Examples of such construction are observed throughout the city, especially in Trešnjevka, Trnje, Dubrava, Kajzerica, Pešćenica-Žitnjak and in the Podsljeme zone (Podsljemenska zona; Figure 3). The central parts of the city that are also the most expensive and offer the highest quality of housing, are dominated by the old housing stock and the most valuable land, faced the influx of various private investors aiming to create the greatest possible profits. Some authors point out that this is a first sign of gentrification, which is not a widespread phenomenon in Zagreb, unlike in many post-socialist cities (Čaldarović, Šarinić, 2008; Svirčić Gotovac, 2010). 
Figure 3: Examples of residential zones in the City of Zagreb: Sopnica-Jelkovec in Sesvete (A), Śpansko-Oranice (B), Kajzerica (C), and (D) Urban villas in Podsljeme zone (Podsljemenska zona; photo: V. Prelogović, 2016).

Slika 3: Primeri stanovanjskih območij v Zagrebu: Sopnica-Jelkovec v Sesvetah (A), ŠpanskoOranice (B), Kajzerica (C), Urbane vile v Podsljemenski coni (D) (foto: V. Prelogović, 2016).

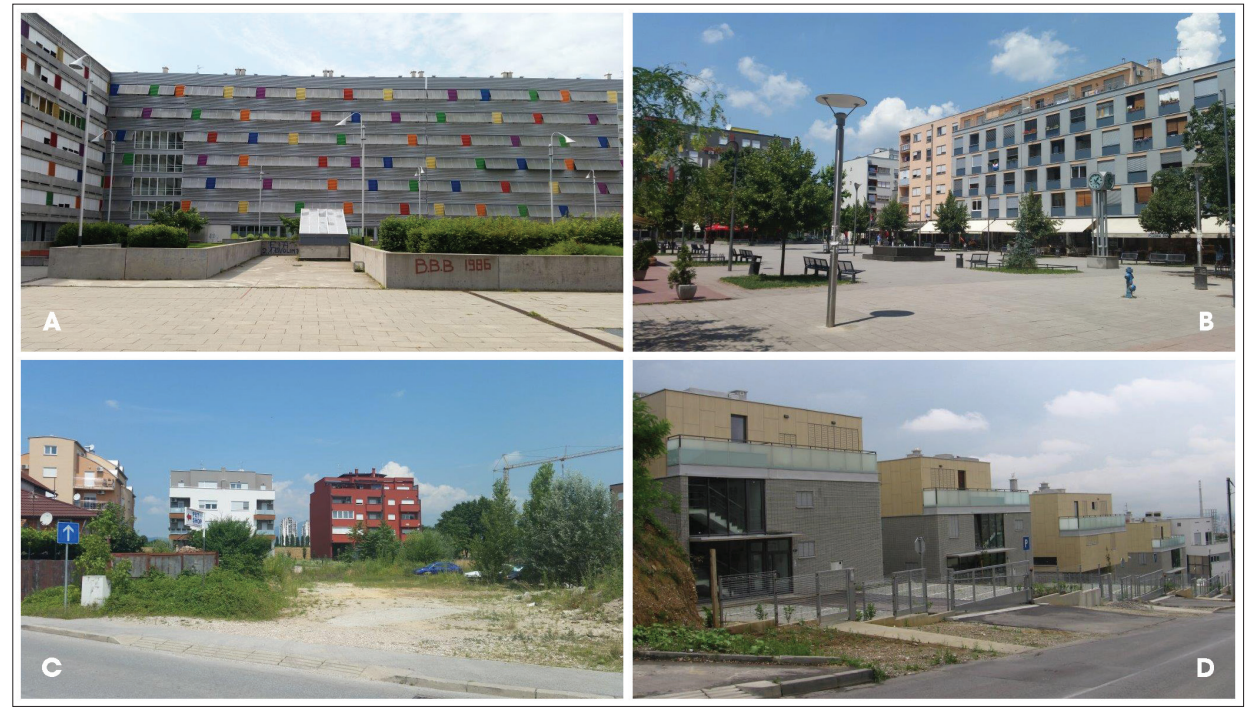

A typical example of inadequate housing, the construction of the so-called "urban villas", was recorded in the late 1990s in the hills of Medvednica, a traditionally elite residential area. These new housing areas reflect the typical transition processes resulting from the lack of spatial planning regulation. The main characteristics of this zone are over-construction, lack of green spaces, and poor availability of basic central functions such as stores.

Three types of housing may be identified in the post-socialist Zagreb, present more or less in all parts of the city, and sometimes a dominant morphological and physiognomic element of the spatial structure. They are the following:

- planned housing developments built with an incentive from the City or the State;

- planned residential areas built by private capital, the so-called commercial construction;

- residential areas including individual and small apartment buildings were built without a clear vision, often outside of the legislative and spatial planning framework.

\subsection{Commercial areas}

Significant changes affected tertiary activities, too, especially retail. The changes are reflected in the location and the organisation with the emergence of new forms of retail trade, i.e. shopping malls. Trade is affected by privatisation, there are new trading companies of local owners and international retail chains are opened. Both processes were present in Croatia during the 1990s, with the arrival of foreign chains 
starting a bit later as a result of the unstable business conditions due to the low purchasing power of citizens, undeveloped real estate market and unsettled ownership relations (Lukić, 2002).

The development of trade became more pronounced since the late 1990s when there was an increase in the purchasing power of the population and changes in consumer habits, or a rise in real estate prices and rents in certain locations within the city. In other words, Zagreb became attractive to foreign investors, which entailed the arrival of foreign retail chains.

Changes in trade began in the central parts of the city, or in the traditional CBD, encompassing the immediate city centre with the central square (Ban Josip Jelačić Square), Zagreb's main shopping street (Ilica), and parts of Frankopanska, Jurišićeva, Vlaška, Masarykova, Teslina, and Petar Preradović Square (Flower Square). It is a prestigious and transport accessible part of the city with valuable historical and cultural buildings, the area with the highest average prices of rent or business premises purchase. Accordingly, in the early 1990s, various shops and supporting commercial facilities (cafés, restaurants, banks, travel agencies, office spaces, etc.) were opened. The concentration of business activities through citification had a negative impact on the lives of the local population and public spaces so there was a decline in housing functions and population.

Shopping malls (shopping centres) certainly represent the biggest innovation in trade. The emergence of shopping centres in Zagreb is related to the increasing importance of tertiary activities, and to the increase in the purchasing power of the population who aims to follow the trend of modern consumer society due to the strengthening of overproduction and consumerism, i.e. the mass consumption of goods and services. In general, there are three types of shopping mall locations in Zagreb: in the city centre, near the major city roads (Zagrebačka avenija, Slavonska avenija, etc.) and near traffic junctions on the outskirts of the city. Considering the functions, the shopping malls of Zagreb may be divided into those in the city centre which, aside from the commercial ones, offer residential, business and social functions, and those in peripheral areas with a predominantly commercial function (Jakovčić, Spevec, 2004).

The first shopping centres in Zagreb were built in the central part of the city during the mid-1990s. The first shopping centre (Importanne centre) was built in 1994 in the area of the Main Railway Station. This was followed by the opening of several shopping centres in the broad city centre, some being located on former industrial land (e.g. Kaptol Centre). After the 2000s, Zagreb witnessed a strong decentralisation of trade and the construction of shopping centres on the outskirts of the city. The first shopping centre on the edge of the city was King Cross, which was built in 2002 near the Jankomir junction, i.e. the Zagreb ring road at the western entrance to the city. 
Table 1: Characteristics of shopping centers in City of Zagreb. Preglednica 1: Značilnosti nakupovalnih središč v Zagrebu.

\begin{tabular}{|l|c|l|c|}
\hline Shopping centre & $\begin{array}{c}\text { Year of } \\
\text { construction }\end{array}$ & Typology by functions & $\begin{array}{c}\text { Gross surface } \\
\text { (in } \mathbf{0 0 0} \mathbf{~ m}^{\mathbf{2}} \text { ) }\end{array}$ \\
\hline Importanne centar & 1994 & shopping mall & 12 \\
\hline Importanne galleria & 1999 & $\begin{array}{l}\text { mixed functions (retail-housing- } \\
\text { business) }\end{array}$ & 15 \\
\hline Mercatone & 2000 & shopping mall & 15 \\
\hline Centar Kaptol & 2000 & $\begin{array}{l}\text { mixed functions (retail-housing- } \\
\text { business) }\end{array}$ & 17 \\
\hline King Cross & 2002 & shopping mall & 10 \\
\hline Branimir centar & 2003 & mixed functions (retail-business) & 50 \\
\hline City Centar One West & 2006 & shopping mall & 26 \\
\hline Avenue Mall & 2007 & mixed functions (retail-business) & 26 \\
\hline Garden Mall & 2009 & shopping mall & 80 \\
\hline West Gate & 2009 & shopping mall & 59 \\
\hline Arena Centar & 2010 & shopping mall & 8 \\
\hline Centar Cvjetni & 2011 & mixed functions (retail-housnig) & 15 \\
\hline Green Gold Centar & 2011 & shopping mall & 30 \\
\hline City Centar One East & 2012 & shopping mall & $\mathbf{4 5 3}$ \\
\hline Point Shopping Centar & 2013 & shopping mall & 13 \\
\hline Ban centar & 2013 & mixed functions (retail-housnig) & 30 \\
\hline Shopping centar Supernova & 2014 & shopping mall & \\
\hline TOTAL & & & \\
\hline
\end{tabular}

Source/Vir: Jakovčić, Spevec, 2004; Zane nekretnine, 2016.

The rapid development of shopping centres has occurred after 2006. Most shopping centres of a newer generation have an average size of over $20,000 \mathrm{~m}^{2}$, including catering functions aside from the commercial ones.

Apart from shopping sites, shopping centres became the premises for the realisation of social and cultural functions, and some of them have even become a kind of tourist attractions. Thus they increasingly started to change the traditional public space and become a metaphor for the semi-public space with the main purpose of consumption, but also offering the possibility of spending free time and socialising (Lukić, 2002; Zlatar, 2013). This trend has been observed in almost all shopping centres, which means that the development of the city in the last 20 years has focused on the consumer economy, which has led to uniformity and loss of identity of the city.

\subsection{Business zones}

One of the main features of the functional and morphological changes in the postsocialist Zagreb is the increase in office premises and the formation of a new CBD (Sić, 2007). The dynamic development of business activities was accompanied by the 
construction of office buildings in the eastern part of Trnje, specifically in the area between the streets of Vukovarska, Heinzelova, Zavrtnica and Radnička cesta (Figure 4). The new CBD has grown at the site of the former industrial complex. Today skyscrapers and large commercial buildings, with branch offices of local and foreign companies, dominate the aforementioned space.

Figure 4: New CBD with business buildings in Radnička street (photo: V. Prelogović, 2016). Slika 4: Novi CBD s poslovnimi stavbami na Radnički ulici (foto: V. Prelogović, 2016).

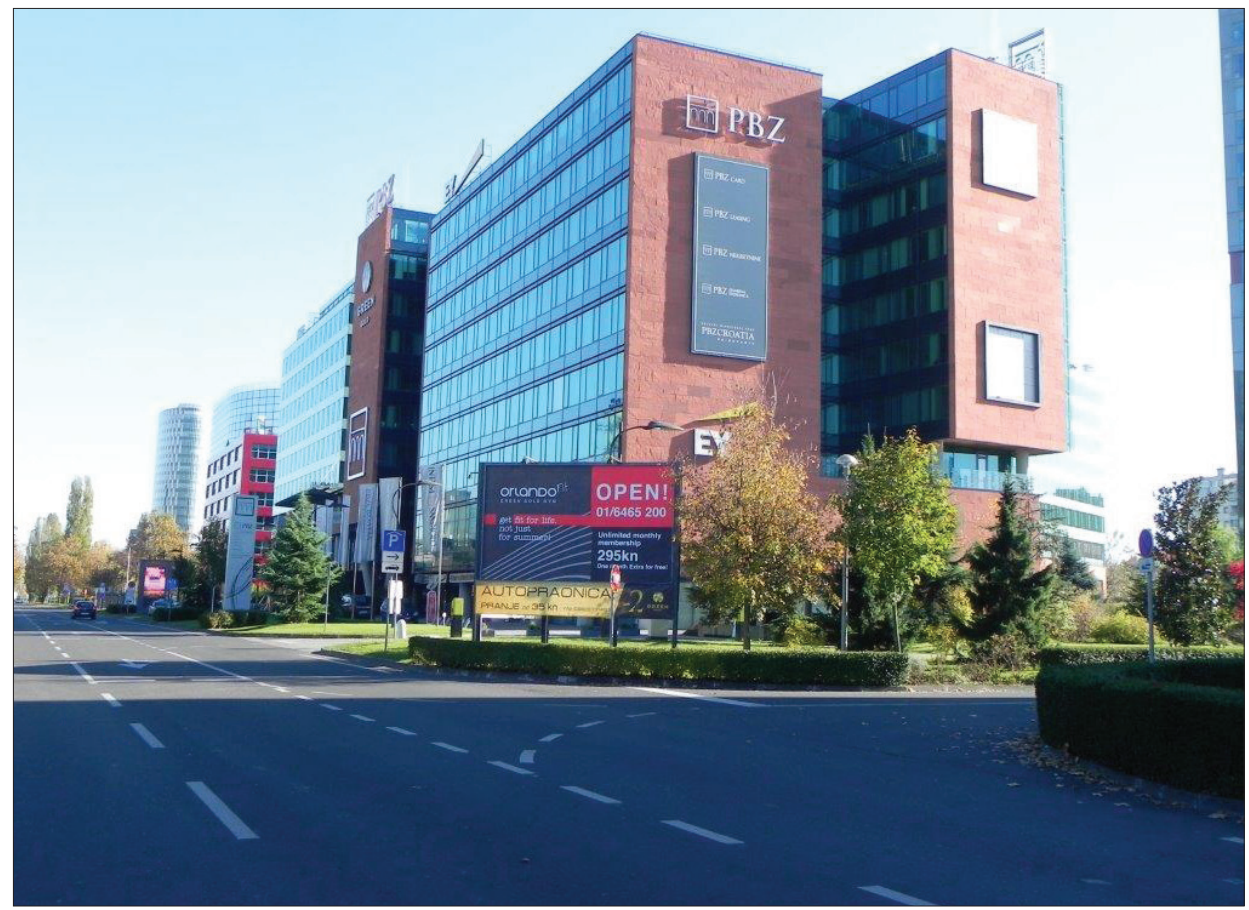

Conversion of land and construction of office buildings point to growing internationalisation or contribute to painting an imitation of Western cities through the construction of large office buildings and skyscrapers that act as symbols of financial and economic elites (Zlatar, 2013). It should be noted that the construction started following the changes to the Master Plan, allowing the construction of commercial and residential skyscrapers higher than nine floors after more than 20 years. In this sense, the sites where there was free land or land suitable for conversion were mostly used.

The construction of office buildings was also present in other parts of the city, and the prominent examples are Savska cesta, Ulica grada Vukovara, Zagrebačka avenija and Buzin Trade Zone on the southern outskirts of Zagreb, by the road to the airport.

Zlatar (2013) points out that this situation in which the towers are scattered throughout the city reflects the impossibility of urban planners and other experts in place to 
determine whether there will be a formation business clusters of skyscrapers such as those in the Anglo-American cities or the construction of high-rise skyscrapers in the area of low family houses will continue. In most cases, the new buildings were not built in accordance with existing regulations and spatial planning documents. This means that the public interest was compromised by the joint activities of political and economic stakeholders. On this basis, business buildings are being inserted in the already built zones which creates huge problems because most of space located near them does not have the infrastructure to withstand new skyscrapers. This results in the reduction of public space, over-construction and a lack of utilities and transport infrastructure, especially parking. However, there are positive arguments for the construction of this type of office buildings, because they enable the implementation of modern architecture, have tourism potential, and adapt to the standards of green building.

\subsection{Industrial and military areas}

In the today's area of Zagreb, there are a number of locations that make up neglected and unused areas from the pre-socialist and socialist period. Land plots of old industrial and military complexes are a great resource for future development, and especially those located near the city centre.

Today many of them decay, regardless of their historical, cultural and architectural value. They are located in almost all parts of the city, the following ones being especially prominent: cement factory "Sloboda" in Podsused, knitwear factory "Nada Dimic", oil factory "Zvijezda", factory of railway vehicles "Gredelj", cookware factory "Gorica", factory of alcoholic beverages "Badel", and the barracks in Borongaj and Črnomerec.

The knitwear factory "Nada Dimić", parts of which were destroyed by fire during the preparation for the construction of new residential and commercial complex, can serve as an example of an abandoned industrial space. Although it is protected as a cultural monument at a valuable location near the Main Station, it is still waiting for its redevelopment. Another example of the city authorities' neglect of the protection and development of the industrial heritage is the demolition of the industrial complex Paromlin which is also the most important protected cultural monument of Zagreb industrial heritage. Parts of the plant burned in a fire in the late 1980s and its future use has not been resolved to date.

This and many other examples point to a series of non-compliances with the regulation, which actually undermines the public interest. Conservation and renovation of buildings are often not performed because such interventions are more expensive for investors, and since most of those sites are owned by the city, which bought them, they are now perishing due to the lack of clear vision of the future use and financial resources. If a new public content is not built on these sites, they will become an object of interest for the entrepreneurs, which will result in the construction of new residential and commercial complexes. Such interventions are supported by existing legislation, which allows bypassing the creation of detailed spatial plan, i.e. implementing parts of the Master Plan.

Some factories have been converted into business premises, such as the former tobacco factory in Klaićeva Street (building "Adris") or the company "Gorica" which hosts 
catering objects. On the periphery, slightly larger land is converted to residential areas, the most prominent being the already mentioned housing estate Sopnica-Jelkovec on the site of the former pig farm "Sljeme" in Sesvete.

The former military land has undergone a somewhat better fate. Under the subsidised housing policy, the large housing estate Špansko-Oranice was built at the site of the Špansko military barracks. The barracks in Borongaj converted into a University campus in the east, while a part of the barracks in Črnomerec was ceded to the Croatian Catholic University.

\section{CONCLUSION}

The transitional period has left an indelible mark in the spatial structure of Zagreb over the last 20 years. Understanding the development of post-socialist Zagreb is very complex, since there was a change in the political, economic, social and cultural spheres in a very short period. The complexity of the transition period is evident in the actions of the interior (national, regional, local) and external (global) processes that are reflected in the specific transformation processes in the spatial structure of the city, expressed mainly in residential, commercial and business functions and the conversion of industrial-military land.

The reflection of transitional changes which altered the power relations in the space affected the "on the fly" adoption of frequently unrelated laws and spatial planning documents, thus failing to prevent negative patterns of development, but creating new ones. It is increasingly difficult to respond to the needs of economic development by means of spatial planning and adopted documents. A number of private initiatives and free decisionmaking led to inadequate infrastructure and architectural solutions throughout the urban area, which fail to contribute to the urban renewal of the city and long-term needs of the population. As in many post-socialist cities, the ideas defined in local (general) master plans are generally not implemented. This was influenced by the very fast restructuring of the legislative and institutional framework of planning. Furthermore, the development and strengthening of the market and spatial planning were influenced by the neo-liberal doctrine, to which a range of private initiatives and a number of actors had to be adapted in the new conditions. Economic stakeholders act in favour of their own interests, which often comes into conflict with civil stakeholders. Legal acts managing urban processes are frequently amended and adapted to the current situation in which individual citizens, investors, developers, private contractors and construction companies enter inadequate spatial patterns. The spatial structure of Zagreb was changed in the transition period as a reflection of the complex relationship between economy, politics and the activities of spatial planning.

We are able to confirm that the development of Zagreb in the transitional conditions was defined by the emergence of new urban structures in the city. The privatisation and introduction of the private sector in spatial planning significantly guided the development of the city. The new legislative framework established by the disintegration of socialism reduced the influence of political actors in spatial planning and insufficiently trained the 
local community to act, while the modified power relations have not been affirmed as leading holders of spatial planning in the new socio-economic context. The criticism of the academic community, the citizens of Zagreb and the growingly important NGO sector highlights the lack of coordination between the stakeholders and the dominance of individual stakeholders, particularly the economic ones. The above shows the necessity of redefinition of their influence and spatial planning activities.

\section{(Translated by Jasenka Kuček)}

\section{References}

Act on Counties, Cities and Municipalities [Zakon o područjima županija, gradova $i$ općina]. 1992. Official Gazette, 90/1992.

Act on Spatial Planning [Zakon o prostornom uređenju]. 1994. Official Gazette, 30/1994; with amendments 68/1998, 61/2000, 32/2002, 100/2004.

Act on Spatial Planning and Construction [Zakon o prostornom uređenju i gradnji]. 2007. Official Gazette, 76/2007.

Bassand, M., 2001. Za obnovu urbane sociologije - jedanaest teza. Sociologija, 43, $345-352$.

Bašić, K., 2005. Apsolutna decentralizacija u populacijskom razvoju Zagrebačke aglomeracije. Hrvatski geografski glasnik, 67, 1, 63-80.

Cavrić, B., Nedović-Budić, Z., 2007. Urban Development, Legislation, and Planning in Post-Socialist Zagreb. In: Stanilov, K. (ed.). The Post-Socialist City: Urban Form and Space Transformations in Central and Eastern Europe After Socialism. Dordrecht, Springer, pp. 385-413.

Crljenko, I., 2012. Utjecaj nekih sociogeografskih čimbenika na morfogenezu zagrebačke Dubrave. Hrvatski geografski glasnik, 74, 1, 111-139.

Čaldarović, O., 2012. Urbano planiranje nekad i sad - tranzicijsko društvo i njegov urbanizam. In: Svirčić Gotovac, A., Zlatar, J. (eds.). Akteri društvenih promjena u prostoru; transformacija prostora i kvalitete života u Hrvatskoj. Zagreb, Institut za društvena istraživanja u Zagrebu, pp. 29-39.

Čaldarović, O., Šarinić, J., 2008. First Signs of Gentrification? Urban Regeneration in the Transitional Society: the Case of Croatia. Sociologija i prostor, 46, 3-4, 369-381.

Dimitrovska Andrews, K., 2005. Mastering the Post-Socialist City: Impacts on Planning the Built Environment. In: Hamilton, I. F. E., Dimitrovska Andrews, K., Pichler-Milanović, N. (eds.). Transformation of Cities in Central and Eastern Europe. Towards Globalization. Tokyo, New York, London, United Nations University Press, pp. 153-186.

Gulin-Zrnić, V., 2013. Nema alternative (?): urbane promjene u Zagrebu na prijelazu stoljeća. In: Čapo, J., Gulin-Zrnić, V. (eds.) Hrvatska svakodnevica - etnografija vremena i prostora, Zagreb, Institut za folkloristiku, pp. 31-63.

Jakovčić, M., 2006. Business Functions and Problem of Closure of Commercial Premises in Ilica Street in Zagreb. Hrvatski geografski glasnik, 68, 1, 27-50. 
Jakovčić, M., Spevec., D., 2004. Trgovački centri u Zagrebu. Hrvatski geografski glasnik, $669,1,47-66$.

Jukić, T., 2012. Strateški projekti u kontekstu provedbe urbanističkih planova-komparacija hrvatskih i europskih iskustava, In: Svirčić Gotovac, A., Zlatar, J. (eds.) Akteri društvenih promjena u prostoru; transformacija prostora i kvalitete života u Hrvatskoj. Zagreb, Institut za društvena istraživanja u Zagrebu, pp. 39-51.

Kostinskiy, G., 2001. Post-Socialist Cities in Flux. In: Paddison, R. (ed.). Handbook of Urban Studies. London, Sage, pp. 451-465.

Kovács, Z., 1999. Cities from State-Socialism to Global Capitalism: an Introduction. GeoJournal, 49, 1, 1-6.

Lukić, A., 2002. Socijalne funkcije trgovačko-poslovnog središta: primjer Centra Kaptol u Zagrebu. Hrvatski geografski glasnik, 64, 73-94.

Master Plan (Generalni urbanistički plan Zagreba). 2015. Službene stranice Grada Zagreba. URL: http://www.zagreb.hr/default.aspx?id=89066 (1.10.2016).

Mlinar, I., 2009. Zagrebačka stambena naselja nakon 2000. godine. Prostor, 17, 1, 159-169.

Mrak-Taritaš, A., 2008. Urbanistički plan uređenja. Uloga i značenje na primjeru grada Zagreba. Prostor, 16, 2, 232-245.

Pegan, S., 2012. Planiranje promjena u prostoru. In: Svirčić Gotovac, A., Zlatar, J. (eds.). Akteri društvenih promjena u prostoru; transformacija prostora i kvalitete života $\mathrm{u}$ Hrvatskoj. Zagreb, Institut za društvena istraživanja u Zagrebu, pp. 131-140.

Prelogović, V., 2004. The Socio-spatial Structure of a City: the Example of Zagreb. Hrvatski geografski glasnik, 66, 1, 29-46.

Prelogović, V., 2009. Primjena faktorske analize u istraživanju socio-prostorne strukture grada: primjer Zagreba. Hrvatski geografski glasnik, 71, 1, 67-85.

Seferagić, D., 2007. Akteri društvenih promjena u urbanom prostoru Hrvatske. Sociologija i prostor, 45, 3-4, 361-376.

Sić, M., 2007. Spatial and functional changes in recent urban development of Zagreb. Dela, 27, 5-15.

Slavuj, L., Cvitanović, M., Prelogović, V., 2009. Emergence of Problem Areas in the Urban Structure of Post-Socialist Zagreb. SPATIUM International Review, 21, 76-83.

Statistical Yearbook of the City of Zagreb (Statistički ljetopis Grada Zagreba) 1999. Gradski zavod za planiranje razvoja grada i zaštitu okoliša, Zagreb, 128 pp.

Statistical Yearbook of the City of Zagreb (Statistički ljetopis Grada Zagreba) 2015. Gradski ured za strategijsko planiranje i razvoj grada, Zagreb, 179 pp.

Svirčić Gotovac, A., 2010. Aktualni gentrifikacijski i revitalizacijski procesi na primjeru Zagreba. Sociologija i prostor, 48, 2, 197-221.

Svirčić Gotovac, A., 2012. Akteri društvenih promjena u prostoru (2007-2011). In: Svirčić Gotovac, A., Zlatar, J. (eds.). Akteri društvenih promjena u prostoru; transformacija prostora i kvalitete života u Hrvatskoj. Zagreb, Institut za društvena istraživanja u Zagrebu, pp. 11-29.

Svirčić Gotovac, A., Zlatar, J., 2015. Urban Processes in Zagreb. Residential and Commercial Developments. Hrvatski geografski glasnik, 77, 1, 29-45. 
Sýkora, L., 1994. Local Urban Restructuring as a Mirror of Globalization Processes: Prague in the 1990s. Urban Studies, 31, 7, 1149-1166.

Sýkora, L., 1999. Changes in the Internal Spatial Structure of Post-Communist Prague. GeoJournal, 49, 1, 79-89.

Zane nekretnine. URL: http://www.zane.hr/wps/wcm/connect/9f483577-1cdb-4ce9-a728-26a695f7099a/IX+brosura+zane.pdf?MOD=AJPERES\&CACHEID=9f483577-1cdb-4ce9-a728-26a695f7099a (1.10.2016).

Zlatar, J., 2013. Urbane transformacije suvremenog Zagreba-sociološka analiza. Zagreb, Institut za društvena istraživanja, Plejada, 215 pp.

\section{PROSTORSKO NAČRTOVANJE IN PREOBRAZBE PROSTORSKE STRUKTURE ZAGREBA}

\section{Povzetek}

Prispevek predstavlja značilnosti razvoja Zagreba v obdobju tranzicije, ki ga obravnava $\mathrm{z}$ analizo razvoja prostorskega načrtovanja in spremenjenih odnosov moči. Predstavlja glavne urbane preobrazbe, značilne za zadnjih dvajset let. $Z$ vidika strateškega razmišljanja in javnega interesa je bil Zagreb v tranzicijskem obdobju izjemno ogrožen zaradi negativnih posegov v stanovanjsko gradnjo, trgovske in poslovne cone ter preobrazbe industrijskih in vojaških območij. Raziskava je osredotočena na mesto Zagreb, prostorsko in administrativno enoto, ki znotraj 17 mestnih okrožij na površini $641 \mathrm{~km}^{2}$ vključuje 70 naselij, med drugim dve mestni naselji (Zagreb in Sesvete, ki sta popolnoma zliti z vidika morfologije in fiziognomije).

Zagreb ima dolgo tradicijo prostorskega načrtovanja, na katero so vplivali raznovrstni družbenogospodarski in politični pogoji, v katerih se je mesto razvijalo. Od sredine 19. stoletja, ko so bili pripravljeni prvi prostorski načrti, so sprejeli številne načrte za usmerjanje razvoja mesta. Druga polovica 20. stoletja je bila zelo pomembno obdobje uveljavitve prostorskega načrtovanja $\mathrm{v}$ praksi, kar je sovpadlo $\mathrm{z}$ intenzivno in dinamično prostorsko širitvijo, prebivalstveno in gospodarsko rastjo. V začetku 90-ih let 20. stoletja so se spremenili odnosi med načrtovalci in drugimi deležniki lokalnega razvoja (npr. javnost, mestna vlada in gospodarski akterji); njihove odnose je vse bolj zaznamoval bolj fleksibilen pristop do prostora (Cavrić, Nedović-Budić, 2007). Neodvisnosti Hrvaške so sledile politične in institucionalne spremembe, ki so močno vplivale na prostorsko načrtovanje v novih družbenogospodarskih, tj. tranzicijskih okoliščinah (Mrak-Taritaš, 2008). V obdobju tranzicije je trg postal glavni regulacijski mehanizem pri načrtovanju razvoja mesta. $\mathrm{V}$ kontekstu slabitve načrtovalskega sistema je vedno večji pomen pridobivalo zasebno vlaganje v zemljišča, ki so postala glavni vir razvojne politike. Poudarek je bil predvsem na posameznih investicijah, kar vodi k odsotnosti širših razvojnih vidikov, obenem pa tudi izključevanju relevantnih deležnikov.

Urbana preobrazba Zagreba je v prispevku pojasnjena s podrobno analizo stanovanjskih, trgovskih, poslovnih in industrijsko-vojaških območij. Tranzicijske spremembe so pomembno vplivale na bivalno funkcijo Zagreba. V obdobju od 1991 do 2014 je bilo v 
Zagrebu zgrajenih 83.883 stanovanj. V prvih 15 letih tranzicije je bilo zgrajenih 29,7 $\%$ stanovanj (24.927). To fazo tranzicije so zaznamovali: vojna in povojni dogodki ter skromnejše gospodarske priložnosti. Pravi razrast v gradnji stanovanj in glavne spremembe na trgu nepremičnin so se pričele v prvih letih 21. stoletja, kar je pustilo neizbrisen pečat $\mathrm{v}$ funkciji in morfologiji mesta. Ključna faza $\mathrm{v}$ stanovanjski gradnji se je pojavila $\mathrm{V}$ obdobju 2001-2010, ko je bil zabeležen vsakoletni porast. Vrh je bil dosežen v letih 2006, 2007 in 2008, ko je bilo zgrajenih več kot 6000 stanovanj v enem letu (8895 stanovanj v letu 2007 in 8744 v letu 2008). 57,3 \% vseh stanovanj, zgrajenih v tranzicijskem obdobju, je bilo zgrajenih med tem graditeljskim valom. Večja motnja v gradbeništvu je prišla leta 2010, ko se je nepričakovano pojavil upad pri novogradnjah kot posledica ekonomske krize: leta 2014 je bilo zgrajenih le 638 stanovanj, kar je 14-krat manj kot v rekordnem letu 2007. V postsocialističnem Zagrebu je mogoče prepoznati tri tipe stanovanjske gradnje: načrtovana stanovanjska gradnja na pobudo mesta ali države; načrtovana stanovanjska gradnja, ki jo je investiral zasebni kapital; t. i. »komercialna gradnja«, pri kateri gre za stanovanjsko gradnjo, ki vključuje individualno gradnjo in gradnjo manjših stanovanjskih enot brez jasne vizije, pogosto izven pravnega in prostorsko načrtovalskega okvirja.

Ena glavnih značilnosti funkcionalnih in morfoloških sprememb v postsocialističnem Zagrebu je dinamičen razvoj pisarniških prostorov in oblikovanje novega CBD-ja (Sić, 2007). Dinamičen razvoj poslovnih dejavnosti je spremljala izgradnja poslovnih prostorov v vzhodnem delu Trnja, zlasti med Vukovarsko, Heinzelovo, Zavrtniško in Radničko ulico. Novi CBD raste na območju nekdanjega industrijskega kompleksa, kjer danes dominirajo nebotičniki in velike trgovske stavbe s podružničnimi pisarnami domačih in tujih podjetij.

Na preučevanem območju Zagreba so številne lokacije, ki so neurejene in neuporabljene še iz časa pred- in socialističnega obdobja. Zemljiške parcele (zlasti tiste, ki so blizu mestnega središča) starih industrijskih in vojaških kompleksov so pomemben prostorski potencial za prihodnji razvoj. Številna tovrstna zemljišča in stavbe propadajo ne glede na njihovo zgodovinsko, kulturno in arhitekturno vrednost.

V tranzicijskih pogojih je bil razvoj Zagreba definiran s pojavom novih urbanih struktur v mestu. Privatizacija in vključevanje zasebnega sektorja v prostorsko načrtovanje je pomembno usmerjalo razvoj mesta. Novi pravni okvir, ki je bil osnovan z razpadom socializma, je zmanjšal vpliv političnih akterjev v prostorskem načrtovanju in je nezadostno usposobil lokalno skupnost za delovanje, medtem ko se spremenjeni odnosi moči niso izkazali kot uspešni pri prostorskem načrtovanju v novem družbenogospodarskem kontekstu. Kritičnost akademske skupnosti, prebivalcev Zagreba in rastoča pomembnost nevladnega sektorja kažejo na pomanjkanje usklajenosti med deležniki in prevlado posameznih deležnikov, zlasti gospodarskih. Zapisano nakazuje potrebo po ponovni opredelitvi tako njihovega vpliva kot tudi aktivnosti prostorskega načrtovanja.

(V slovenski jezik prevedla Irma Potočnik Slavič) 